\title{
Are ABO Blood Groups and Rh Factor Risk Factors for Hypertensive Diseases of Pregnancy?
}

\section{ABO Kan Grupları ve Rh Faktörü Gebeliğin Hipertansif Hastalıkları için Risk Faktörü mü?}

\author{
(D) Osman Uzundere1, (1) Cem Kıvılcım Kaçar², (1) Cengiz Andan³, (1) Abdulkadir Yektaș4
}

${ }^{1}$ Diyarbakır Obstetrics and Gynecology Hospital, Clinic of Anesthesiology and Reanimation, Diyarbakır, Turkey

2University of Health Sciences, Diyarbakır Gazi Yașargil Training and Research Hospital, Clinic of Anesthesiology and Reanimation, Diyarbakır, Turkey ${ }^{3}$ Diyarbakır Obstetrics and Gynecology Hospital, Clinic of Obstetrics and Gynecology, Diyarbakır, Turkey

${ }^{4}$ University of Health Sciences, Diyarbakır Gazi Yașargil Training and Research Hospital, Clinic of General Intensive Care Unit, Diyarbakır, Turkey

\begin{abstract}
Introduction: The primary aim of our study was to investigate the relationship between hypertensive diseases of pregnancy (HDP) and blood groups. Our secondary aim is to determine the risk factors that play a role in the development of HDP.

Methods: Pregnant women aged 15-49 years were included in this cross-sectional, observational, and prospective study. Pregnant women were divided into two groups. Group 1 $(n=266)$ included patients admitted to the intensive care unit due to HDP. Group 2 ( $n=402$ ) included normotensive patients without any complications during pregnancy. The groups were compared in terms of age, blood groups, Rh factor, gravida, parity, gestational week, and primiparity-multiparity.

Results: There was no statistically significant difference between the groups in terms of ABO blood group and Rh factor. The mean age, gravida, and parity were significantly higher in Group 1 than in Group 2 ( $p=0.028 ; 0.001 ; 0.004$, respectively), while mean gestational age was lower than Group $2(p<0.001)$. We also found that high gravida, low gestational age, presence of comorbidity, and primiparity were risk factors for HDP.

Conclusion: We did not find any relationship between HDP and blood groups. We found that high gravida, low gestational age, presence of comorbidity, and primiparity are risk factors for HDP.
\end{abstract}

Keywords: ABO blood group, Rh factor, hypertensive diseases of pregnancy, risk factors

\section{öZ}

Amaç: Çalıșmamızın öncelikli amacı gebeliğin hipertansif hastalıkları (GHH) ile kan grupları arasındaki ilișkiyi incelemektir. Ikincil amacımız ise GHH'lerin gelișiminde rol oynayan risk faktörlerini belirlemektir.

Yöntemler: Kesitsel, gözlemsel ve prospektif olarak planlanan çalışmamıza 15-49 yaș arası gebeler dahil edildi. Gebeler iki gruba ayrıldı. Grup $1 \quad(n=266), G H H$ nedeniyle yoğun bakım ünitesine kabul ettiğimiz hastalar; grup $2(n=402)$, gebelik süresince herhangi bir komplikasyon gelișmeyen ve normotansif olan hastalardan oluștu. Gruplar yaş, kan grupları, Rh faktörü, gravida, parite, gebelik haftası ve primiparitemultiparite açısından karșılaștırıldı.

Bulgular: Gruplar arasında ABO kan grubu ve Rh faktörü açısından istatistiksel olarak anlamlı bir fark saptanmadı. Grup 1 'in yaș, gravida ve parite ortalaması grup 2'ye göre istatistiksel olarak anlamlı bir şekilde daha yüksek saptanırken (sırasıyla, $\mathrm{p}=0,028 ; 0,001 ; 0,004)$, gebelik haftası ortalaması grup 2'ye göre daha düşük idi $(p<0,001)$. Ayrıca yüksek gravida, düșük gebelik haftası, komorbidite varlığı ve primiparitenin GHH için risk faktörleri olduğunu saptadık.

Sonuç: Çalıșmamızda GHH ile kan grupları arasında herhangi bir ilișki saptamadık. Yüksek gravida, düșük gebelik haftası, komorbidite varlığı ve primiparitenin GHH için risk faktörleri olduğunu gösterdik.

Anahtar Kelimeler: ABO kan grubu, Rh faktörü, gebeliğin hipertansif hastalıkları, risk faktörleri

\section{Introduction}

Many risk factors such as age, parity, history of preeclampsia, multiple pregnancy, comorbidities [Diabetes Mellitus (DM), chronic hypertension, etc.], history of thrombophilia and obesity have been defined related to hypertensive diseases of pregnancy (HDP), which is the cause of approximately $18 \%$ of maternal deaths in the world (Table 1) (1,2). Factors for Hypertensive Diseases of Pregnancy?. İstanbul Med J 2020; 21(1): 53-7.

(c) Copyright 2020 by the Istanbul Training and Research Hospital/istanbul Medical Journal published by Galenos Publishing House

(C) Telif Hakkı 2020 istanbul Ĕgitim ve Araștırma Hastanesi/Istanbul Tıp Dergisi, Galenos Yayınevi tarafından basıImıștır.
Address for Correspondence/Yazışma Adresi: Osman Uzundere MD, Diyarbakır Obstetrics and Gynecology Hospital, Clinic of Anesthesiology and Reanimation, Diyarbakır, Turkey

Phone: +90 5330206362 E-mail: osmanuzundere@gmail.com ORCID ID: orcid.org/0000-0002-5968-4561

Cite this article as/Atıf: Uzundere 0, Kaçar CK, Andan C, Yektaș A. Are ABO Blood Groups and Rh Factor Risk fully understood (3). Although it is not known, oxidative stress in the spiral arterioles in the placenta and endothelial dysfunction developed by various mediators may be responsible for the pathogenesis of preeclampsia (3). One of the risk factors identified for preeclampsia is the history of thrombophilia (4). Due to being a risk factor for preeclampsia, thrombophilia increased the interest in $\mathrm{ABO}$ blood groups that play an essential role in coagulation by interacting with factor VIII and von
Received/Gelis Tarihi: 13.02.2019 Accepted/Kabul Tarihi: 22.10.2019 
Willebrand factor (5). Studies have shown that bleeding is more common in people with blood group 0 and that thromboembolic events and ischemic heart diseases are more common in people with other blood types (6-8).

Different results have been found in studies investigating the relationship between preeclampsia and $\mathrm{ABO}$ in different parts of the world. While no relationship has been reported between preeclampsia and blood groups in some studies (9-12), other studies have reported an association between preeclampsia and blood groups $A, A B$, or 0 (1317). These conflicting results also were observed in our country $(11,17)$. We aimed to investigate the relationship between HDP and ABO blood group-Rh factor and contribute to the literature by examining the factors that play a role in the development of HDP in Diyarbakır Obstetrics and Gynecology Hospital, where the patient density is much higher than most hospitals in our country.

\section{Methods}

After the approval of the University of Health Sciences, Gazi Yașargil Training and Research Hospital Ethics Committee (decision no: 27, date: February 16, 2018), our study was carried out between February 20, 2018, and February 01, 2019, in Diyarbakır Obstetrics and Gynecology Hospital, where there are approximately 24.000 births annually. Our study was planned as a cross-sectional, prospective, and observational study. Pregnant women aged 15-49 years were included in the study. Pregnant women were divided into two groups. Group $1 \quad(n=266)$ included the patients who were hospitalized and followed up in the intensive care unit (ICU) due to HDP. Group $2(n=402)$ was randomly selected among normotensive and follow-up patients who did not develop any complications during pregnancy. Patients under the age of 15 , patients older than 49 years, patients who were pregnant and hospitalized in the ICU for non-HDP reasons, and those hospitalized in the ICU after gynecological surgeries were not included in the study. This study was conducted in accordance with the Helsinki Declaration 2008 criteria.

Age, blood group, Rh factor, gravida, parity, gestational week, comorbidities, and primiparity-multiparity status of the patients were recorded. Also, the length of ICU stay of group 1 patients was recorded. The groups were firstly compared in terms of blood groups and Rh

Table 1. Risk factors for preeclampsia*

Primiparity

History of preeclamptic pregnancy

Chronic hypertension, chronic kidney disease or both

History of thrombophilia

Multiple pregnancies

In vitro fertilization

Family history for preeclampsia

Type 1 or type 2 Diabetes Mellitus

Obesity

Systemic lupus erythematosus

Advanced maternal age $(>40)$

*: Hypertension in pregnancy. American College of Obstetricians and Gynecologists, 2013 factor, and then in terms of other factors. Then, statistically significant values were considered as independent risk factors, and estimated relative risk and $95 \%$ confidence interval $(\mathrm{Cl})$ were calculated by logistic regression analysis.

\section{Statistical Analysis}

SPSS 16.0 for Windows program was used for statistical analysis. Statistical data were expressed as mean and standard deviation (SD), and categorical data were expressed as number and percentage. The comparison of the categorical data was made with a chi-square test, and the results were given as $\mathrm{n}(\%)$. The Kolmogorov-Smirnov test was used to determine whether the non-categorical data showed normal distribution. Mann-Whitney $\mathrm{U}$ test was used because the data did not show normal distribution. Results regarding numerical data were given as mean \pm SD. Age, gravida, parity, gestational age, comorbidity, and primiparity-multiparity status were accepted as independent risk factors for HDP and evaluated by logistic regression. $\mathrm{P}<0.05$ was accepted as statistically significant.

\section{Results}

A total of 668 patients were included in the study. The mean age of the patients included in the study was $30.30 \pm 6.73$ years, gravida was $3.22 \pm 2.1$, parity was $2.81 \pm 1.75$, and the gestational week was $36.73 \pm 2.98$. One hundred and twenty-nine patients (19.3\%) were primiparous, and 539 patients (81.7\%) were multiparous. Thirty-one patients (4.6\%) had comorbidity. The most frequent comorbidities were hypertension, anemia, and DM. The most frequently observed blood group was A blood group (264 patients, 39.5\%), and 591 patients (88.5\%) were Rh (+). Blood group and Rh types according to groups are shown in Graphs 1, 2.

Of all patients admitted to the ICU due to HDP (group 1), 23 (8.64\%) had pregnancy-related hypertension, 229 had (86.09\%) preeclampsia, 10 (3.75\%) had eclampsia, and four (1.5\%) had HELLP syndrome. The mean length of ICU stay was $2.25 \pm 0.79$ days.

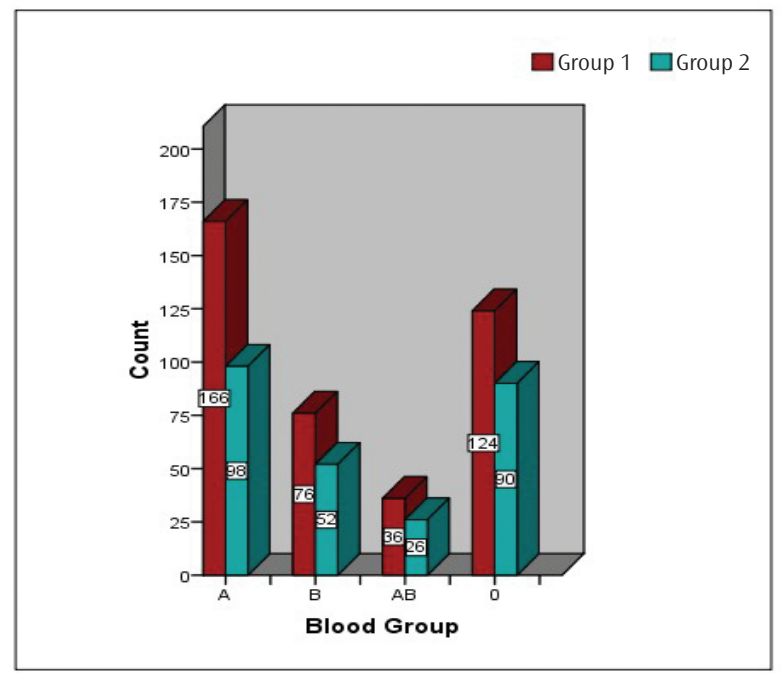

Graphic 1. Blood group frequency in groups 
When group 1 and group 2 were compared in terms of age, gravida, parity, and gestational week, the following results were observed: The mean age of group 1 was higher than group 2, and this difference was statistically significant $(p=0.028)$. The mean gravida and parity of group 1 were also significantly higher than group $2(p=0.001$ and 0.004 , respectively). The mean gestational age of the patients in group 1 was found to be significantly lower than group $2(p<0.001)$ (Table 2$)$.

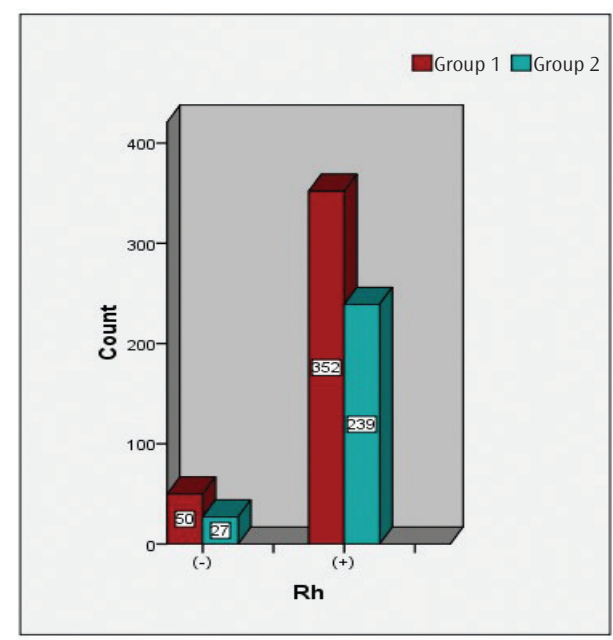

Graphic 2. Distribution of groups according to Rh factor
When group 1 and group 2 were evaluated in terms of primiparitymultiparity, it was found that HDP developed more than expected in the primiparous, and this difference was statistically significant ( $p=0.001)$. When group 1 and group 2 were evaluated in terms of comorbidity, it was found that HDP developed more than expected in patients with comorbidity, and this difference was statistically significant $(p<0.001)$. When group 1 and group 2 were compared in terms of blood groups and Rh factor, no statistically significant difference was found between the groups ( $p=0.706$ and 0.365 , respectively) (Table 3 ).

The logistic regression analysis performed by accepting age, gravida, parity, gestational week, comorbidity and primiparity-multiparity status as independent risk factors for HDP revealed that high gravida [odds ratio (OR): 1.43, 95\% $\mathrm{Cl}: 1.142-1.811, \mathrm{p}=0.02$ ], low gestational week (OR: $0.59,95 \% \mathrm{Cl}: 0.527-0.666, \mathrm{p}<0.001$ ), the presence of comorbidity (OR: 4.64, 95\% Cl: 1.817-11.662, $\mathrm{p}=0.001$ ) and primiparity (OR: 0.152, 95\% $\mathrm{Cl}: 0.084-0.274, \mathrm{p}<0.001)$ were found to be independent risk factors for HDP (Table 4).

\section{Discussion}

In studies examining the relationship between preeclampsia and $\mathrm{ABO}$ blood groups in HDP, it has been reported that AB blood group is mostly associated with preeclampsia, and blood group A was also reported in some studies (14-18). Compared to other blood groups, Placental protein 13 was reported to bind more strongly to $A B$ blood group (15). Also, high

Table 2. Comparison of groups in terms of age, gravida, parity and gestational age

\begin{tabular}{|c|c|c|c|}
\hline & Group $1(\text { Mean } \pm S D)^{1}$ & Group 2 (Mean \pm SD) & $p^{*}$ \\
\hline Age & $31.04 \pm 7.37$ & $29.81 \pm 6.21$ & 0.028 \\
\hline Gravida & $3.86 \pm 2.64$ & $2.81 \pm 1.52$ & 0.001 \\
\hline Parity & $3.26 \pm 2.28$ & $2.51 \pm 1.20$ & 0.004 \\
\hline Gestational age & $35.09 \pm 3.92$ & $37.80 \pm 1.27$ & $<0.001$ \\
\hline
\end{tabular}

Table 3. Comparison of groups in terms of blood group, Rh factor, primiparity-multiparity and comorbidity

\begin{tabular}{|l|l|l|l|}
\hline Blood group & Group 1(n) (\%) & Group 2 (n) (\%) & p \\
\hline A & $98(37.12)$ & $166(62.88)$ \\
\hline B & $52(40.62)$ & $76(59.38)$ & 0.706 \\
\hline AB & $26(41.93)$ & $36(58.07)$ \\
\hline 0 & $90(42.05)$ & $124(57.95)$ \\
\hline Rh & $239(40.45)$ & $352(59.55)$ \\
\hline$(+)$ & $27(35.06)$ & $50(64.94)$ \\
\hline$(-)$ & & $61(47.28)$ \\
\hline Primiparity-multiparity & $68(52.72)$ & $341(63.27)$ \\
\hline Primiparous & $198(36.73)$ & 402 \\
\hline Multiparous & 266 & 0.365 \\
\hline Total & & $9(2.2)$ \\
\hline Comorbidity & $22(8.3)$ & $393(97.8)$ \\
\hline$(+)$ & $244(91.7)$ & $402(100 \%)$ \\
\hline$(-)$ & $266(100 \%)$ & \\
\hline Total & & -001 \\
\hline \#: Chi-square test result p-value & & \\
\hline
\end{tabular}




\begin{tabular}{|c|c|c|}
\hline Risk Factor & $\operatorname{RR}(95 \% \mathrm{Cl})^{*}$ & $p^{* *}$ \\
\hline Age & $0.99(0.965-1.034)$ & 0.94 \\
\hline Gravida & $1.43(1.142-1.811)$ & 0.02 \\
\hline Parity & $1.204(0.917-1.581)$ & 0.182 \\
\hline Gestational age & $0.59(0.527-0.661)$ & $<0.001$ \\
\hline Comorbidity & $4.64(1.817-11.662)$ & 0.001 \\
\hline Primiparity-multiparity & $0.152(0.084-0.274)$ & $<0.001$ \\
\hline
\end{tabular}

levels of coagulation factors (including factor VIII and von Willebrand factor) leading to preeclampsia and triggering pathophysiological events were reported in women with $A B$ blood group (11). The fact that thromboembolic events are more common in other blood groups compared to the 0 blood group is another evidence supporting the association between the $A B$ blood group and preeclampsia $(15,18)$. However, there are studies in the literature indicating that there is no relationship between preeclampsia and the ABO blood group (9-12). In these studies, other factors (such as obesity, cardiovascular disease, and hypertensive diseases) were suggested to play a role in the development of preeclampsia except for the ABO blood group (9). In our study, no relationship was found between preeclampsia and $\mathrm{ABO}$ blood groups. However, in accordance with some publications in the literature, we found that the presence of comorbidity in pregnant patients (hypertension, DM) is a risk factor for the development of HDP.

There are some studies in the literature examining the relationship between the Rh factor and preeclampsia. Sharami et al. (12) stated that $\mathrm{Rh}(-)$ is a significant risk factor for moderate and severe preeclampsia and that the reason for this may be an immunological incompatibility between mother and fetus. Lee et al. (15) reported that women with Rh $(+)$ had a slightly increased risk for HDP and preeclampsia. Avci et al. (17) also reported that $\mathrm{Rh}(+)$ was a risk factor in the development of preeclampsia and postpartum hypertension. The ratio of people with $\mathrm{Rh}(+)$ factor in our country is between $83.7-90.83 \%$, and the ratio of Rh (-) is between $9.17-16.30 \%$ (19). In our study, $88.5 \%$ of the patients were $\mathrm{Rh}(+)$, and $11.5 \%$ were $\mathrm{Rh}(-)$, reflecting the general population. However, we could not find any relationship between the Rh factor and HDP in our study.

In the literature, various risk factors for HDP have been described in various publications. One of these publications is the guideline for hypertension in pregnancy, published in 2013 by The American College of Obstetricians and Gynecologists (4). In addition to the risk factors described in this guideline, in 2016, Rezk et al. (20) stated that having a history of miscarriage might be a risk factor for the development of preeclampsia. In our study, in accordance with the literature, we detected the presence of comorbidity and primiparity as risk factors for HDP development. Another result of our study, which was consistent with the literature, was that the mean age of patients with HDP was statistically higher than the control group. We think that increased frequency of preeclampsia with increasing age may be related to the increase in the incidence of chronic hypertension and other comorbid diseases with advanced age. Oxidative stress and endothelial dysfunction due to hypertension, DM, and many other chronic diseases may increase the risk of developing preeclampsia. In addition to these risk factors, we found that high gravida and low gestational age were also risk factors for preeclampsia. We could not find any literature examining the relationship between gravida and preeclampsia. In most of the studies in the literature, parity and primiparity-multiparity status were examined for preeclampsia $(1,10,13,21,22)$. The fact that patients with high gravida are older, and the possibility of comorbidity increases with older age may cause preeclampsia to be seen more frequently in this patient group.

In their study, Khader et al. (22) reported that the incidence of preeclampsia was high in pregnant women with a gestational age of $\leq 31$ weeks. In our study, we found that the gestational week was lower in the HDP group than the control group and that the low gestational week was a risk factor for preeclampsia. We believe that this result was due to the control group, including full-term pregnancies without any problems (mean gestational age: $37.8 \pm 1.27)$ and HDP group, including mostly preterm pregnant women (mean gestational age: $35.09 \pm 3.92$ ). Pregnancy was terminated by cesarean section in most cases in order to maintain the well being of mother and fetus in HDP group.

\section{Conclusion}

No significant relationship was found between HDP and ABO blood groups and Rh factor. We found that high gravida, low gestational age, presence of comorbidity, and primiparity were risk factors for HDP. We think that more comprehensive studies on HDP, which is one of the most important diseases of the pregnancy that has many unclarified issues related to its pathophysiology, will contribute to understanding the pathophysiology of the disease and reducing maternal morbidity and mortality.

Ethics Committee Approval: After the approval of the University of Health Sciences, Gazi Yaşargil Training and Research Hospital Ethics Committee (decision no: 27, date: 16/02/2018).

Informed Consent: Informed consent was obtained from the parents of the children.

Peer-review: Externally peer-reviewed.

Author Contributions: Concept - O.U., A.Y.; Design - O.U., C.K.K., C.A., A.Y.; Data Collection and/or Processing - O.U., C.K.K., C.A.; Analysis and/ or Interpretation - O.U., A.Y.; Literature Search - O.U., C.K.K., C.A., A.Y.; Writing Manuscript - 0.U.

Conflict of Interest: No conflict of interest was declared by the authors.

Financial Disclosure: The authors declared that this study received no financial support.

\section{References}

1. Duckitt K, Harrington D. Risk factors for pre-eclampsia at antenatal booking: Systematic review of controlled studies. BMJ 2005; 330: 565.

2. Abalos E, Cuesta C, Carroli G, Qureshi Z, Widmer M, Vogel JP, et al. "Preeclampsia, eclampsia and adverse maternal and perinatal outcomes: A secondary analysis of the World Health Organization Multicountry Survey on Maternal and Newborn Health. BJOG 2014; 121 (Suppl 1): 14-24. 
3. Mirkovic L, Nejkovic L, Micic J. A new pathophysiological concept and new classification of pre-eclampsia. Vojnosanit Pregl 2018; 75: 83-94.

4. American College of Obstetricians and Gynecologists, issuing body. [DNLM: 1. Hypertension, Pregnancy-Induced-Practice Guideline. WQ 244] RG575.5 618.3'6132-dc23, 2013022521

5. Mital P, Gupta D, Benwal DK, Gangwal H, Hooja N, Agarwal S, et al. To find any association of maternal blood group as a risk factor for preeclampsia. Int J Community Med Public Health 2016; 3: 3445-49.

6. Larsen TB, Johnsen SP, Gislum M, Møller CA, Larsen H, Sørensen HT. ABO blood groups and risk of venous thromboembolism during pregnancy and the puerperium. A population-based, nested case - control study. J Thromb Haemost 2005; 3: 300-4.

7. Capuzzo E, Bonfanti C, Frattini F, Montorsi P, Turdo R, Previdi MG, et al. The relationship between $\mathrm{ABO}$ blood group and cardiovascular disease: Results from the Cardiorisk program. Ann Transl Med 2016; 4: 189.

8. Franchini M, Marano G, Vaglio S, Catalano L, Pupella S, and Liumbruno G. $M$. The role of ABO blood type in thrombosis scoring systems. Semin Thromb Hemost 2017; 43: 525-9.

9. Hentschke MR, Caruso FB, Paula LG, Medeiros AK, Gadonski G, Antonello IC, et al. Is there any relationship between $\mathrm{ABO} / \mathrm{Rh}$ blood group and patients with pre-eclampsia? Pregnancy Hypertens 2014; 4: 170-3.

10. Aghasadeghi F, Saadat M. Association between ABO and Rh blood groups and risk of preeclampsia: A case-control study from Iran. Open Access Maced J Med Sci 2017; 5: 173-6.

11. Beyazit F, Pek E, Güngör AÇ, Gencer M, Unsal MA. Effect of maternal ABO blood type on birth weight and preeclampsia. Int J Reprod Contracept Obstet Gynecol 2017; 6: 2164-7.

12. Sharami SH, Zendehdel M, Mirblouk F, Asgharnia M, Faraji R, Heirati SFD, et al. Comparison of preeclampsia risk factors regarding to severity with control group. Zahedan J Res Med Sci 2017; 19:e5008.
13. Elmugabil A, Rayis DA, Ahmed MA, Adam I, Gasim Gl. O blood group as risk factor for preeclampsia among Sudanese women. Open Access Maced J Med Sci 2016; 4: 603-6.

14. Phaloprakarn C, Tangjitgamol S. Maternal ABO blood group and adverse pregnancy outcomes. J Perinatol 2013; 33: 107-11.

15. Lee BK, Zhang Z, Wikman A, Lindqvist PG, Reilly M. ABO and RhD blood groups and gestational hypertensive disorders: A population-based cohort study. BJOG 2012; 119: 1232-7.

16. Franchini M, Mengoli C, Lippi G. Relationship between ABO blood group and pregnancy complications: A systematic literature analysis. Blood Transfus 2016; 14: 441-8.

17. Avci D, Karagoz H, Ozer O, Esmeray K, Bulut K, Aykas F, et al. Are the blood groups of women with preeclampsia a risk factor for the development of hypertension postpartum? Ther Clin Risk Manag 2016; 12: 617-22.

18. Manjunatha S, Anita K. The relationship between maternal blood group and preeclampsia. Int J Reprod Contracept Obstet Gynecol 2015; 4: 1749-52.

19. Özkasap S, Dereci S, Sahin K, Dilek AR, Kalyoncuoğlu E, Zengin T. Analysis of $\mathrm{ABO}$ and Rh blood groups distribution in East Karadeniz region of Turkey. Dicle Med J 2013; 40: 100-4.

20. Rezk M, Abo-Elnasr M, Al Halaby A, Zahran A, Badr H. Maternal and fetal outcome in women with gestational hypertension in comparison to gestational proteinuria: A 3-year observational study. Hypertens Pregnancy 2016; 35: 181-8.

21. Bilano VL, Ota E, Ganchimeg T, Mori R, Souza JR. Risk factors of pre-eclampsia/ eclampsia and its adverse outcomes in low- and middle-income countries: A WHO secondary analysis. PLoS One 2014; 9: 1-9.

22. Khader YS, Batieha A, Al-njadat RA, Hijazi SS. Preeclampsia in Jordan: Incidence, risk factors, and its associated maternal and neonatal outcomes. J Matern Fetal Neonatal Med 2018; 31: 770-6. 